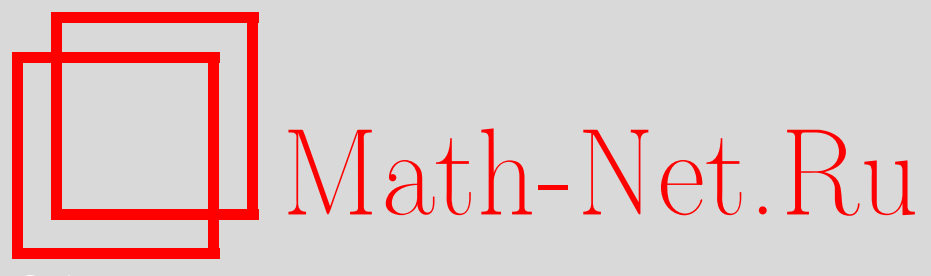

Н. Н. Андреев, "Математические этюды" - новая форма традиции, УМН, 2009, том 64, выпуск 4, 205-206

DOI: https://doi.org/10.4213/rm9310

Использование Общероссийского математического портала Math-Net.Ru подразумевает, что вы прочитали и согласны с пользовательским соглашением http://www . mathnet.ru/rus/agreement

Параметры загрузки:

IP: 3.85 .5 .30

26 апреля 2023 г., 09:01:32

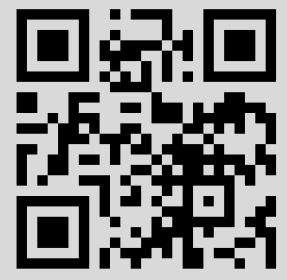




\section{“Математические этюды" - новая форма традиции}

\section{Н. Н. Андреев}

Проект "Математические этюды" (http://etudes.ru) развивает уникальные российские традиции в области естественно-научной популяризации, представляя в увлекательной форме решенные и нерешенные математические задачи. Основное наполнение - короткометражные фильмы, выполненные с использованием трехмерной компьютерной графики.

Проект реализуется в стенах Математического института им. В. А. Стеклова РАН с 2002 г. Многие идеи для фильмов родились в общении с сотрудниками института. За время работы проекта создано более 40 фильмов и 35 миниатюр на темы из самых разных разделов математики и ее приложений, например: кривые на плоскости, внутренняя и внешняя геометрия многогранников, задачи дискретной геометрии о наилучшем расположении точек. Наряду с сюжетами, традиционно используемыми в научно-популярной литературе, в фильмах представлены и интересные математические результаты, полученные в последние годы. Фильмы рассказывают не только о математических идеях, но и о приложениях к технике, об истории рассматриваемых вопросов, ученых и инженерах, принимавших участие в их решении. Каждый фильм сопровождается научно-популярной статьей и ссылками для дальнейшего изучения рассматриваемых вопросов.

Большая и важная тематика, выделенная в отдельный проект - "Механизмы П. Л. Чебышёва" (http://tcheb.ru). В рамках проекта компьютерно моделируются все плоские шарнирные механизмы, а также устройства, созданные на их основе, придуманные великим математиком. Среди них первая в мире шагающая машина (названная Чебышёвым "стопоходящей”), “сортировалка", “самокатное кресло", "гребной" механизм. Некоторые устройства и механизмы хранятся в Политехническом музее (Москва), в Музее истории Санкт-Петербургского университета, в Музее искусств и ремесел (Париж). По договоренности с этими музеями компьютерные модели механизмов создаются на основе тщательного измерения всех параметров оригиналов. Сохранение в моделях размеров всех дета-

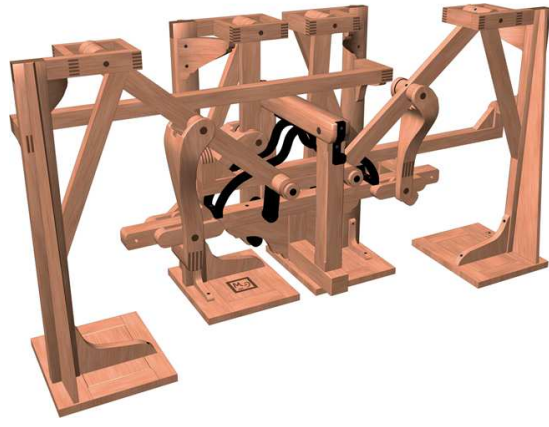
лей механизмов позволит (в случае необходимости) изготовить точные копии этих устройств. Утраченные механизмы восстанавливаются по архивным документам. В фильмах, посвященных этой тематике, демонстрируется как принцип действия механизмов, так и их математическая основа - приближение заданной линии (отрезок, дуга окружности, полная окружность и др.) шатунной кривой.

Цикл фильмов о плоских шарнирных механизмах не исчерпывается историческими сюжетами. В проекте рассказывается и о современных математических задачах 
этой области, и о возможном использовании шарнирных механизмов в преподавании математики. Пример - наглядное представление композиции преобразований.

Целевая аудитория проекта - школьники (и естественно-научного и гуманитарного профиля), школьные учителя, студенты, преподаватели вузов, все интересующиеся математикой. Много нового и интересного найдут в фильмах и профессиональные ученые, в том числе математики.

Основная цель проекта - увлечь зрителя математикой, показать ее внутренюю красоту и важность для познания мира. Другая задача - наше общество должно иметь более полное представление о достижениях академической науки, в частности, в области математики.

Компьютерная графика выбрана как средство популяризации математики по двум причинам. Визуальное представление упрощает для многих понимание математических идей. Кроме того, компьютерная графика сама по себе привлекает современную молодежь.

Для реализации изложенных идей привлечены профессионалы из разных областей: 3D-графику в фильмах делает М. А. Калиниченко; двумерную графику, дизайн и программирование интернет-сайтов осуществляет Р. А. Кокшаров, изготовление математических моделей и другую деятельность проекта - Н. Л. Шавельзон. Математические расчеты для фильмов проводит Н. М. Панюнин; большую помощь по проекту оказывает Е. А. Зёрнышкина. Для работы над фильмами и другими задачами проекта привлекается и талантливая молодежь. Например, математические миниатюры для телефонов іPhone создает студент мехмата МГУ Антон Фонарёв. С 2008 г. проект “Математические этюды" поддерживается Фондом Дмитрия Зимина “Династия".

Все фильмы представлены в открытом доступе на "полянке" Математических этюдов в сети Интернет. Посещаемость сайта - более 5 тысяч пользователей в день. Проект стал победителем ряда конкурсов и фестивалей. По материалам проекта читается более 60 научно-популярных лекций в год в больших и малых городах России. Доклады о проекте были сделаны на семинарах ведущих математических институтов страны и научных конференциях. 